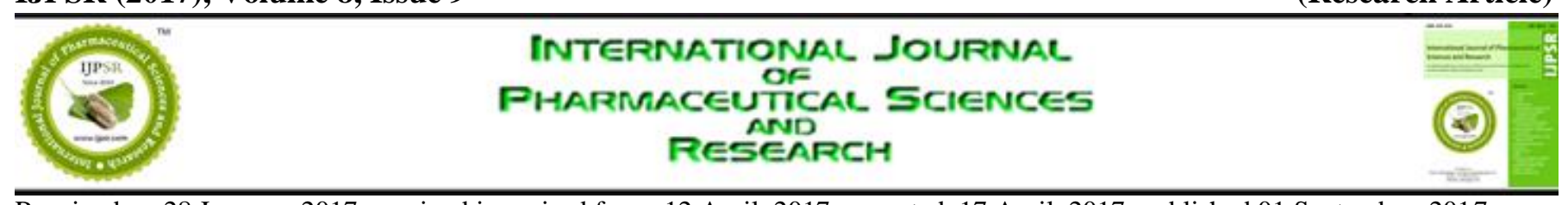

Received on 28 January, 2017; received in revised form, 12 April, 2017; accepted, 17 April, 2017; published 01 September, 2017

\title{
MOLECULAR DOCKING STUDIES OF NOVEL IMIDAZOLE ANALOGS AS HIV-1-RT INHIBITORS
}

Rohit Singh * and Swastika Ganguly

Department of Pharmaceutical Science and Technology, Birla Institute of Technology, Ranchi - 835215, Jharkhand, India.

Keywords:

Imidazole,

Non-nucleoside reverse transcriptase inhibitors, Docking, HIV

Correspondence to Author:

\section{Rohit Singh}

Research Scholar,

Department of Pharmaceutical

Science and Technology, Birla

Institute of Technology, Ranchi

- 835215, Jharkhand, India.

Email: rohitsingh20485bitmesra@gmail.com

\begin{abstract}
Molecular docking studies of 102 newly designed Nsubstituted imidazoles was performed in the non nucleoside inhibitory binding pocket of reverse transcriptase enzyme of wild type as well as resistant strains of HIV-1 virus with PDB ID 1RT2, 1JLB, 3BGR and 1FK9 respectively by using Glide 5.0 to carry out a binding mode analysis of the designed imidazoles. Results generated from this study indicate that most of the compounds dock into the active site of different enzymes such as 1RT2, 1JLB, 3BGR and 1FK9 showing excellent Docking scores comparable to the standard TNK 651 . Compounds SRS 21, SRS 34, SRS 45, SRS 46, SRS 73, SRS 76 and SRS 77 exhibited the highest docking scores and were found to be most effective as compared to standard TNK 651.
\end{abstract}

INTRODUCTION: HIV-1 Reverse Transcriptase: Reverse transcriptase is a key enzyme which plays an important role in the replication of human immunodeficiency virus (HIV-1) and is thus useful in AIDS therapy ${ }^{1}$. Human immunodeficiency virus, also called retrovirus, has two subtypes i.e. HIV-1 (occurs worldwide) and HIV-2 (found mainly in Africa), consist of a single stranded RNA genome which is converted into double stranded DNA. This conversion occurs in the cytoplasm of newly HIV infected cell in the presence of a viral enzyme named as reverse transcriptase ${ }^{2}$. The currently available drugs for AIDS therapy are protease inhibitors, nucleoside reverse transcriptase inhibitors (NRTIs) and non-nucleoside reverse transcriptase inhibitors (NNRTIs) ${ }^{3,4}$.

\begin{tabular}{|c|c|}
\hline QUICK RESPONSE CODE & $\begin{array}{c}\text { DOI: } \\
\text { 10.13040/IJPSR.0975-8232.8(9).3751-57 }\end{array}$ \\
\cline { 2 - 2 } & $\begin{array}{c}\text { Article can be accessed online on: } \\
\text { www.ijpsr.com }\end{array}$ \\
\hline DOI link: http://dx.doi.org/10.13040/IJPSR.0975-8232.8 (9).3751-57
\end{tabular}

The currently available drugs for AIDS therapy are protease inhibitors, nucleoside reverse transcriptase inhibitors (NRTIs) and non-nucleoside reverse transcriptase inhibitors (NNRTIs) 3, 4. Unlike nucleoside analogs, non nucleoside reverse trancriptase inhibitors (NNRTI's) bind in a noncompetitive manner to a specific pocket of HIV-1 RT and alters the viral replication mechanism by acting as a chain terminator ${ }^{5,6}$. From the literature survey, it was observed that the butterfly like shape is important factor in the binding of the first generation NNRTIs.

Despite their chemical diversity, they assume very similar butterfly-like shape. The butterfly structure has a hydrophilic centre as a 'body' and two hydrophobic moieties representing the 'wings' 7. X-ray crystallographic studies reveals that NNRTI's posses's butterfly like' conformation and appear to function as pi electron donors surrounding binding pocket. Presently three NNRTI's namely nevirapine, delavirdine, and efavirenz are commercially available in clinical 
practice. Combination of these NNRTI's with NRTI's and protease inhibitors (PI's) are used in the treatment of most cases of HIV infected patients. Three NNRTIs, nevirapine (Viramune1), delavirdine (Rescriptor1) and efavirenz (Sustiva1, Stocrin1) were approved for the treatment of HIV infection in 1996, 1997 and 1998, respectively. They became cornerstones of HIV therapy because of their full potential as a component of HAART ${ }^{8}$. Nevirapine is also one of the few agents that are used to prevent mother-to-child transmission of HIV. In contrast to NtRTIs, they display a unique anti-retroviral activity spectrum that is limited to HIV-1 only.

The NNRTIs are non-competitive inhibitors that bind allosterically to an asymmetric and hydrophobic cavity, about $10 \mathrm{~A}^{\circ}$ away from the catalytic site of the HIV-1 RT ${ }^{9}$. As a result of NNRTI binding, certain RT domains that actively participate in DNA synthesis are restricted in flexibility and mobility which, in turn, leads to a dramatic reduction in catalytic enzyme efficiency 10. Recent studies also point to the interplay between the NRTI and NNRTI binding sites, possibly explaining the synergies between the two classes of RT inhibitors. Nevirapine (NNRTI) was one of the first medicaments with anti-retroviral activity to be treated against humans but that led to a rapid development of resistance associated with loss in clinical efficacy. The main side effect of nevirapine is the appearance of rashes, which are toxic in nature and in few cases Steven Johnson have been reported. While delavirdine and efavirenz generally used in combination and the main side effects are rashes, nausea, and loss of apetite, insomnia and strange dreams.

The NNRTIs nevirapine, delavirdine, and efavirenz (Scheme 1) have been approved for treatment of HIV-1 infection in combinations with other RT and non-RT drugs. As with all classes of anti-HIV-1 drugs, resistant viral strains evolve which severely impair the long-term efficacy of the NNRTIs. This limits the usefulness of NNRTI's ${ }^{11}$. Current antiAIDS therapy is based on drugs that belong either to the class of nucleoside/nucleotide (NRTIs / NtRTIs) and non-nucleoside reverse transcriptase inhibitors. The nucleoside (seven drugs) and nucleotide (one drug) analogues (collectively known as nucleoside reverse transcriptase inhibitors [NRTIs] and nucleotide reverse transcriptase inhibitors [NtRTIs], respectively) are activated by host enzymes to their triphosphate forms, which bind to the active site of RT, where, acting as substrate decoys, they pre-terminate DNA chain elongation during viral DNA synthesis (Fig. 1). (NNRTIs), protease, or entry inhibitors. NNRTIs area structurally diverse group of compounds which interact with a specific allosteric non-substrate binding pocket site of HIV-1 RT (non-nucleoside inhibitor binding pocket), leading to a non-competitive inhibition of the enzyme ${ }^{12}$.

Docking Strategies: Knowledge of the threedimensional (3D) structure of ligand + protein complexes provides a valuable understanding of the function of molecular systems. The rate of protein structure determination is increasing rapidly. Today there are some 5,000 entries in the Brookhaven Protein Data Bank ${ }^{13}$. The number of ligands available to assess and rationalize ligand protein interactions is large. Assuming the receptor structure is available, a primary challenge in lead discovery and optimisation is to predict both ligand orientation and binding affinity; the former is often referred to as 'molecular docking'. Docking methodologies with novel extensions, and the diversity in both their complexity and computational speed provides a plethora of techniques to tackle modern structure based drug design problems ${ }^{14,15}$. The importance of docking in the field of drug design is that it increases computer power and docking performance, it is now possible to dock thousands of ligands in a timeline which is useful to the pharmaceutical industry ${ }^{16}$.

The non-nucleoside inhibitory binding pocket (NNIBP) is mainly a hydrophobic pocket that contains side chains of aromatic amino acid residues Y181, Y188, F227, W229 and Y318 and of hydrophobic amino acid residues P95, L100, V106, V108, V179, L234 and P236 from the p66 subunit ${ }^{17}$.

\section{MATERIAL AND METHOD:}

Computational Docking Study by Glide $\mathbf{5 . 0}$ (Schrodinger Inc; USA): Docking study was performed for all designed compounds (1-102) by glide 5.0 version (ref. schrodinger lnc USA schrodinger LLC Newyork 2008) installed in a single machine running on a $3.4 \mathrm{GHZ}$ Pentium 4 processor with 1 GB RAM and 160 GB hard disk 
with red hat linux enterprise version 8.5 as operating system.

Protein Structure Preparation: The X-ray crystallographic structure of HIV-1 RT complexed with TNK-651(PDB entry code 1RT2), Y181C mutant HIV-1 reverse transcriptase complexed with Nevirapine (PDB entry code 1JLB), Bis heteroaryl piperazine U-90152 (BHAP-U) resistant mutation for HIV-1 RT (PDB entry code 1KLM), K103N/Y181C mutant HIV-1 RT complex with TMC 278 (Rilvirapine) etc were obtained from brookhaven protein data bank (RCSB) ${ }^{8}$. (ref. http:// www.rcsb.org/pdb) for glide docking studies, chain A was retained and all water molecules as well as chain B were removed and missing hydrogen atom were added and structure was optimized since tnk crystallized ligand in the enzyme HIV-1 RT complexed with Tnk-651. 3BGR crystal structures of k103N/Y181C mutant HIV-1 RT in complex with TMC 278 (rilpivirine) which is a nucleoside reverse transcriptase inhibitor.

TMC 278 is a diaryl pyrimidine (DAPY) non nucleoside reverse transcriptase in complex with Nevirapine (PDB entry code 1JLB) and HIV-1 reverse transcriptase complexed with BHAPU90152 (bis heteroaryl piperazine) (PDB entry code 1KLM).

Ligand Structure Preparation: All the designed substituted imidazole compound used in docking study were prepared with glide in maestro 8.5 version of schrodinger Inc. these structures were geometrically optimized potentials for liquid simulations_2005 (OPLS_2005) force field. Partial atomic charges were computed using the OPLS_2005 force field.

Receptor Grid Generation: Shape and properties of receptor were represented on a grid by different set of fields that provide progressively more accurate scoring of ligand poses. Pick the ligand molecule and that was excluded from receptor grid generation. After that scaling of vanderwaals radii of non polar atoms which gave better interaction between receptor and ligand. Scaling of other interaction can also help to model flexibility of parts of the receptor. Appropriate method to determine how closely ligand bound with the receptor during docking procedure.
Docking Study: In this study, docking of TNK 651, Nevirapine, BHAP and Rilpivirine were extracted from protein 1RT2, 1JLB, 1KLM and 3BGR performed to dock with prepared respective proteins in order to dock with prepared respective proteins in order to check reliability and reproducibility of docking protocol for our study. A very good interaction were found between ligand their particular receptor.SH imidazole ring with carbonyl group of lysine and ' $\mathrm{N}$ ' heteroatom of imidazole with hydrogen bond that was $1.909 \mathrm{~A}^{\circ}$ and $2.262 \mathrm{~A}^{\circ}$ respectively which were shown in Fig. 1A and $1 \mathbf{B}$.

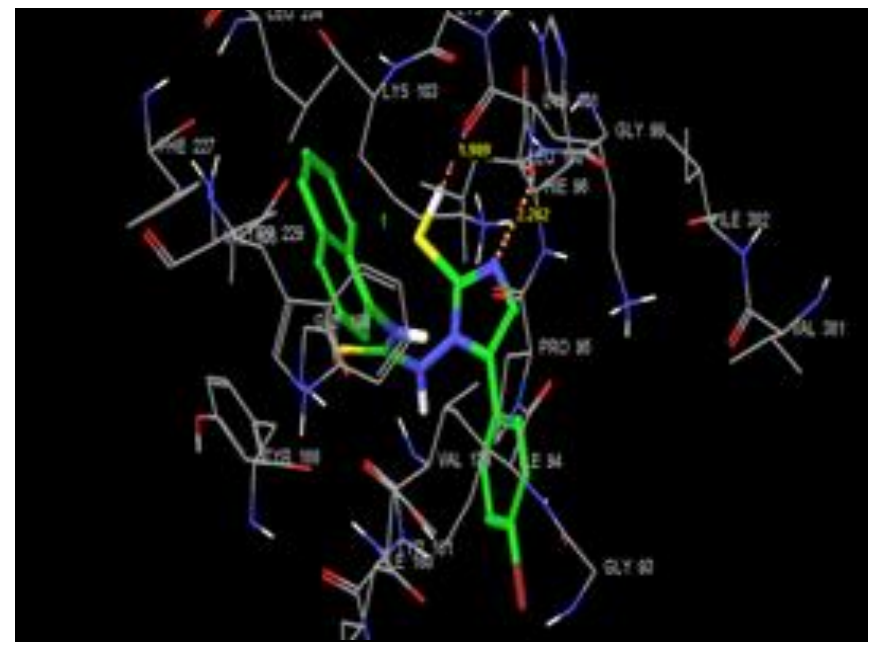

FIG. 1A: MOLECULAR MODEL OF IMIDAZOLE A SERIES (73) IN THE NNRTI OF HIV-1 RT (PDB CODE 1RT2)

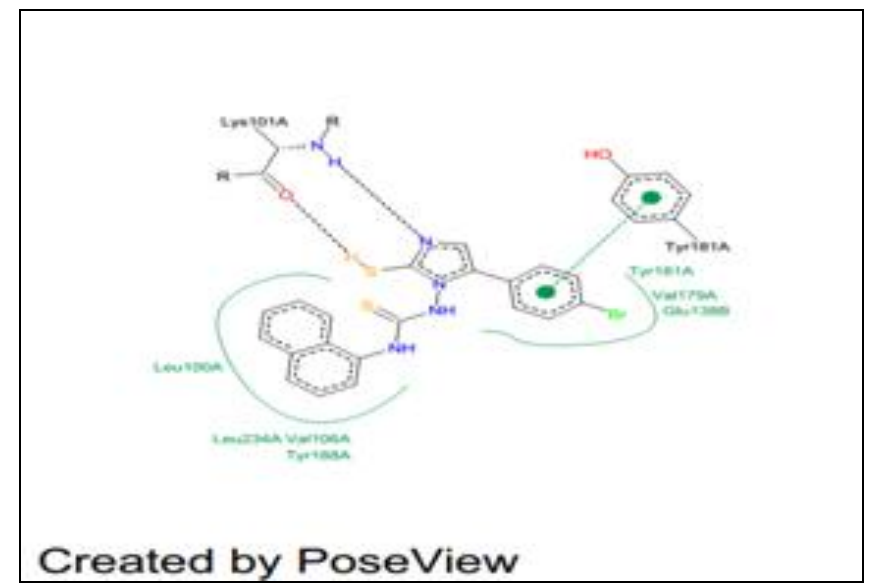

FIG. 1B: SCHEMATIC (2D) REPRESENTATION OF INTERACTIONS OF COMPOUND 73 IN BINDING POCKET OF THE PROTEIN

Active site amino acid residues are represented as lines while the inhibitor is shown as ball and stick model with the atoms colored as carbon: green, hydrogen: cyan, nitrogen: blue, and oxygen: red. Hydrogen bond interactions are represented by pink dotted lines. (SHIMIDAZOLE RING $\mathrm{CO}_{\mathrm{LYS} 101}=$ 
$1.909 \mathrm{~A}^{\circ}$ and $\mathrm{N}$ of imidazole ring_ $\mathrm{NH}_{\mathrm{LYS} 101}=$ $\left.2.262 \mathrm{~A}^{\circ}\right)$. Put the distance of $\mathrm{H}$ bond interactions as shown in sample here (Glide XP Score - 12.47).

The root mean square deviation (RMSD) between extracted ligand and crystallized receptor was carried out by redocking extracted ligand Nevirapine, BHAP, and Relpivirine into the active site of 1JLB, 1KLM and 3BGR. The RMSD found for $1 \mathrm{JLB}, 1 \mathrm{KLM}$ and $3 \mathrm{BGR}$ were a series of designed imidazole derivative analogs (1-102) were used for molecular docking studies on active site of different proteins viz 1RT2, 1JLB, 1KLM and 3BGR by using glide 5.0.

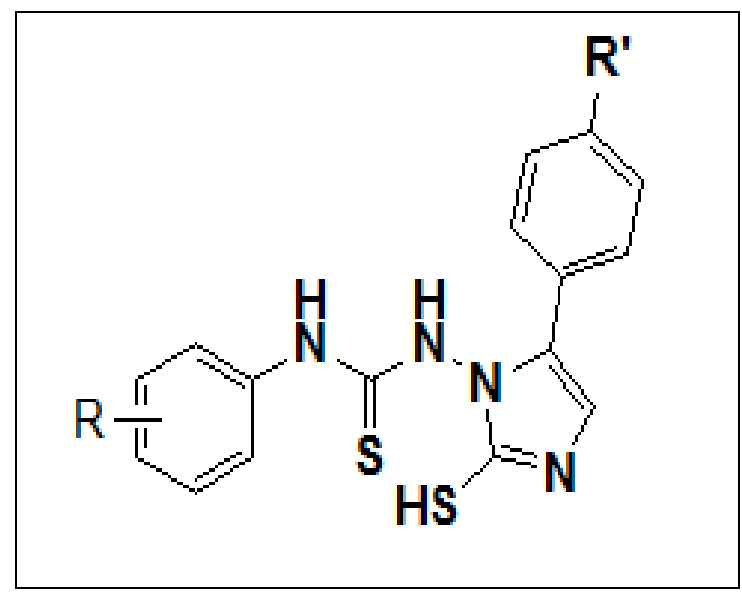

FIG. 2: ??

TABLE 1: THE DOCKING SCORES

\begin{tabular}{|c|c|c|c|c|c|c|}
\hline Compound no. & $\mathbf{R}$ & $\mathbf{R}^{\prime}$ & Dock score on 1RT2 & 1JLB & 1KLM & 3BGR \\
\hline SRS 1 & $\mathrm{H}$ & $\mathrm{Br}$ & -9.27 & -6.83 & -8.69 & -5.89 \\
\hline SRS 2 & $\mathrm{H}$ & $\mathrm{Cl}$ & -9.81 & -8.31 & -9.11 & -11.59 \\
\hline SRS 3 & $\mathrm{H}$ & $\mathrm{CH}_{3} \mathrm{O}$ & -10.55 & -6.92 & -8.69 & -6.66 \\
\hline SRS 4 & $\mathrm{H}$ & $\mathrm{CH}_{3}$ & -8.76 & -7.37 & -11.74 & -11.58 \\
\hline SRS 5 & $\mathrm{H}$ & $\mathrm{NO}_{2}$ & -8.92 & -6.60 & -9.97 & -7.19 \\
\hline SRS 6 & $\mathrm{H}$ & $\mathrm{C}_{6} \mathrm{H}_{5}$ & -11.11 & -7.36 & -7.33 & -7.66 \\
\hline SRS 7 & $3-\mathrm{Cl}$ & $\mathrm{Br}$ & -8.54 & -5.88 & -9.94 & -11.29 \\
\hline SRS 8 & $3-\mathrm{Cl}$ & $\mathrm{Cl}$ & -8.69 & -5.08 & -12.02 & -12.00 \\
\hline SRS 9 & $3-\mathrm{Cl}$ & $\mathrm{CH}_{3} \mathrm{O}$ & -9.06 & -6.60 & -10.05 & -9.18 \\
\hline SRS 10 & $3-\mathrm{Cl}$ & $\mathrm{CH}_{3}$ & -10.34 & -5.35 & -11.78 & -9.52 \\
\hline SRS 11 & $3-\mathrm{Cl}$ & $\mathrm{NO}_{2}$ & -8.99 & -5.52 & -9.58 & -8.66 \\
\hline SRS 12 & $3-\mathrm{Cl}$ & $\mathrm{C}_{6} \mathrm{H}_{5}$ & -9.90 & -5.34 & -9.17 & -7.77 \\
\hline SRS 13 & $4-\mathrm{Cl}$ & $\mathrm{Br}$ & -8.78 & -5.48 & -9.89 & -7.87 \\
\hline SRS 14 & $4-\mathrm{Cl}$ & $\mathrm{Cl}$ & -9.85 & -6.42 & -10.85 & -10.91 \\
\hline SRS 15 & $4-\mathrm{Cl}$ & $\mathrm{CH}_{3} \mathrm{O}$ & -9.68 & -6.04 & -9.76 & -10.11 \\
\hline SRS 16 & $4-\mathrm{Cl}$ & $\mathrm{CH}_{3}$ & -9.80 & -4.85 & -9.58 & -11.88 \\
\hline SRS 17 & $4-\mathrm{Cl}$ & $\mathrm{NO}_{2}$ & -10.01 & -7.27 & -10.06 & -8.19 \\
\hline SRS 18 & $4-\mathrm{Cl}$ & $\mathrm{C}_{6} \mathrm{H}_{5}$ & -10.77 & -6.43 & -9.52 & -7.61 \\
\hline SRS 19 & $2-\mathrm{CH}_{3}$ & $\mathrm{Br}$ & -8.66 & -7.78 & -8.56 & -8.78 \\
\hline SRS 20 & $2-\mathrm{CH}_{3}$ & $\mathrm{Cl}$ & -9.14 & -6.54 & -11.71 & -6.47 \\
\hline SRS 21 & $2-\mathrm{CH}_{3}$ & $\mathrm{CH}_{3} \mathrm{O}$ & -12.02 & -7.15 & -9.07 & -6.64 \\
\hline SRS 22 & $2-\mathrm{CH}_{3}$ & $\mathrm{CH}_{3}$ & -11.25 & -5.88 & -9.17 & -11.22 \\
\hline SRS 23 & $2-\mathrm{CH}_{3}$ & $\mathrm{NO}_{2}$ & -9.47 & -6.61 & -9.43 & -11.93 \\
\hline SRS 24 & $2-\mathrm{CH}_{3}$ & $\mathrm{C}_{6} \mathrm{H}_{5}$ & -9.22 & -5.66 & -8.59 & -6.64 \\
\hline SRS 25 & $4-\mathrm{CH}_{3}$ & $\mathrm{Br}$ & -10.04 & -3.85 & -10.23 & -11.22 \\
\hline SRS 26 & $4-\mathrm{CH}_{3}$ & $\mathrm{Cl}$ & -10.02 & -6.54 & -10.82 & -11.93 \\
\hline SRS 27 & $4-\mathrm{CH}_{3}$ & $\mathrm{CH}_{3} \mathrm{O}$ & -9.95 & -6.03 & -10.17 & -9.99 \\
\hline SRS 28 & $4-\mathrm{CH}_{3}$ & $\mathrm{CH}_{3}$ & -9.77 & -6.49 & -10.61 & -8.40 \\
\hline SRS 29 & 4- $\mathrm{CH}_{3}$ & $\mathrm{NO}_{2}$ & -9.80 & -5.63 & -10.23 & -6.92 \\
\hline SRS 30 & $4-\mathrm{CH}_{3}$ & $\mathrm{C}_{6} \mathrm{H}_{5}$ & -8.50 & -6.49 & -7.36 & -7.64 \\
\hline SRS 31 & $2-\mathrm{NO}_{2}$ & $\mathrm{Br}$ & -8.29 & -5.75 & -8.87 & -8.25 \\
\hline SRS 32 & $2-\mathrm{NO}_{2}$ & $\mathrm{Cl}$ & -8.54 & -5.67 & -8.40 & -8.39 \\
\hline SRS 33 & $2-\mathrm{NO}_{2}$ & $\mathrm{CH}_{3} \mathrm{O}$ & -8.94 & -5.61 & -8.46 & -8.03 \\
\hline SRS 34 & $2-\mathrm{NO}_{2}$ & $\mathrm{CH}_{3}$ & -12.11 & -5.51 & -8.16 & -8.42 \\
\hline SRS 35 & $2-\mathrm{NO}_{2}$ & $\mathrm{NO}_{2}$ & -8.63 & -5.64 & -8.62 & -6.03 \\
\hline SRS 36 & $2-\mathrm{NO}_{2}$ & $\mathrm{C}_{6} \mathrm{H}_{5}$ & -6.82 & -7.29 & -7.23 & -8.02 \\
\hline SRS 37 & $4-\mathrm{NO}_{2}$ & $\mathrm{Br}$ & -8.58 & -3.17 & -11.64 & -10.93 \\
\hline SRS 38 & $4-\mathrm{NO}_{2}$ & $\mathrm{Cl}$ & -8.45 & -7.11 & -12.15 & -11.27 \\
\hline SRS 39 & $4-\mathrm{NO}_{2}$ & $\mathrm{CH}_{3} \mathrm{O}$ & -8.09 & -7.32 & -11.64 & -8.21 \\
\hline SRS 40 & $4-\mathrm{NO}_{2}$ & $\mathrm{CH}_{3}$ & -8.62 & -4.45 & -12.30 & -11.03 \\
\hline SRS 41 & $4-\mathrm{NO}_{2}$ & $\mathrm{NO}_{2}$ & -8.68 & -5.81 & -10.94 & -4.09 \\
\hline SRS 42 & $4-\mathrm{NO}_{2}$ & $\mathrm{C}_{6} \mathrm{H}_{5}$ & -7.12 & -2.73 & -7.35 & -7.52 \\
\hline
\end{tabular}




\begin{tabular}{|c|c|c|c|c|c|c|}
\hline SRS 43 & $3-\mathrm{Cl}, 2-\mathrm{CH}_{3}$ & $\mathrm{Br}$ & -10.03 & -6.74 & -10.28 & -9.24 \\
\hline SRS 44 & $3-\mathrm{Cl}, 2-\mathrm{CH}_{3}$ & $\mathrm{Cl}$ & -11.15 & -6.83 & -9.79 & -9.43 \\
\hline SRS 45 & $3-\mathrm{Cl}, 2-\mathrm{CH}_{3}$ & $\mathrm{CH}_{3} \mathrm{O}$ & -12.14 & -4.86 & -9.71 & -7.35 \\
\hline SRS 46 & $3-\mathrm{Cl}, 2-\mathrm{CH}_{3}$ & $\mathrm{CH}_{3}$ & -12.07 & -4.08 & -9.54 & -8.36 \\
\hline SRS 47 & $3-\mathrm{Cl}, 2-\mathrm{CH}_{3}$ & $\mathrm{NO}_{2}$ & -10.79 & -7.06 & -10.50 & -8.08 \\
\hline SRS 48 & $3-\mathrm{Cl}, 2-\mathrm{CH}_{3}$ & $\mathrm{C}_{6} \mathrm{H}_{5}$ & -7.39 & -6.62 & -9.03 & -7.84 \\
\hline SRS 49 & 2-Cl-6- $\mathrm{CH}_{3}$ & $\mathrm{Br}$ & -9.82 & -5.94 & -9.04 & -8.50 \\
\hline SRS 50 & 2-Cl-6- $\mathrm{CH}_{3}$ & $\mathrm{Cl}$ & -6.49 & -8.40 & -9.61 & -8.85 \\
\hline SRS 51 & 2-Cl-6- $\mathrm{CH}_{3}$ & $\mathrm{CH}_{3} \mathrm{O}$ & -5.98 & -6.28 & -9.08 & -8.36 \\
\hline SRS 52 & 2-Cl-6- $\mathrm{CH}_{3}$ & $\mathrm{CH}_{3}$ & -6.88 & -8.05 & -9.38 & -9.07 \\
\hline SRS 53 & 2-Cl-6- $\mathrm{CH}_{3}$ & $\mathrm{NO}_{2}$ & -9.74 & -5.57 & -9.35 & -7.81 \\
\hline SRS 54 & 2-Cl-6- $\mathrm{CH}_{3}$ & $\mathrm{C}_{6} \mathrm{H}_{5}$ & -6.41 & -5.13 & -7.80 & -7.76 \\
\hline SRS 55 & 3,4-di-Cl & $\mathrm{Br}$ & -11.00 & -7.85 & -9.54 & -7.38 \\
\hline SRS 56 & 3,4-di-Cl & $\mathrm{Cl}$ & -11.00 & -6.33 & -10.94 & -6.46 \\
\hline SRS 57 & 3,4-di-Cl & $\mathrm{CH}_{3} \mathrm{O}$ & -11.36 & -7.91 & -11.52 & -7.91 \\
\hline SRS 58 & 3,4-di-Cl & $\mathrm{CH}_{3}$ & -5.67 & -8.23 & -10.54 & -8.16 \\
\hline SRS 59 & 3,4-di-Cl & $\mathrm{NO}_{2}$ & -9.84 & -6.28 & -9.79 & -7.11 \\
\hline SRS 60 & 3,4-di-Cl & $\mathrm{C}_{6} \mathrm{H}_{5}$ & -8.60 & -6.44 & -9.66 & -7.95 \\
\hline SRS 61 & $4-\mathrm{Br}$ & $\mathrm{Br}$ & -10.23 & -3.50 & -11.76 & -10.89 \\
\hline SRS 62 & $4-\mathrm{Br}$ & $\mathrm{Cl}$ & -8.33 & -4.83 & -12.12 & -10.42 \\
\hline SRS 63 & $4-\mathrm{Br}$ & $\mathrm{CH}_{3} \mathrm{O}$ & -9.20 & -6.16 & -9.20 & -9.47 \\
\hline SRS 64 & $4-\mathrm{Br}$ & $\mathrm{CH}_{3}$ & -6.23 & -6.05 & -11.61 & -11.82 \\
\hline SRS 65 & $4-\mathrm{Br}$ & $\mathrm{NO}_{2}$ & -9.10 & -5.79 & -10.38 & -7.09 \\
\hline SRS 66 & $4-\mathrm{Br}$ & $\mathrm{C}_{6} \mathrm{H}_{5}$ & -7.84 & -6.50 & -9.05 & -8.00 \\
\hline SRS 67 & 2,5 -di- $\mathrm{CH}_{3}$ & $\mathrm{Br}$ & -10.04 & -6.99 & -9.64 & -7.61 \\
\hline SRS 68 & $2,5-\mathrm{di}-\mathrm{CH}_{3}$ & $\mathrm{Cl}$ & -10.38 & -4.38 & -9.60 & -8.46 \\
\hline SRS 69 & 2,5-di- $-\mathrm{CH}_{3}$ & $\mathrm{CH}_{3} \mathrm{O}$ & -10.55 & -5.02 & -10.59 & -8.02 \\
\hline SRS 70 & 2,5 -di- $\mathrm{CH}_{3}$ & $\mathrm{CH}_{3}$ & -7.71 & -7.09 & -9.61 & -8.32 \\
\hline SRS 71 & 2,5-di- $\mathrm{CH}_{3}$ & $\mathrm{NO}_{2}$ & -10.18 & --6.91 & -9.94 & -7.57 \\
\hline SRS 72 & 2,5-di- $-\mathrm{CH}_{3}$ & $\mathrm{C}_{6} \mathrm{H}_{5}$ & -7.00 & -5.94 & -8.99 & -6.54 \\
\hline SRS 73 & $\alpha$ - napthyl & $\mathrm{Br}$ & -12.47 & -9.94 & -8.73 & -10.26 \\
\hline SRS 74 & $\alpha$ - napthyl & $\mathrm{Cl}$ & -9.73 & -9.74 & -11.81 & -10.32 \\
\hline SRS 75 & $\alpha$ - napthyl & $\mathrm{CH}_{3} \mathrm{O}$ & -8.69 & -9.59 & -8.47 & -9.54 \\
\hline SRS 76 & $\alpha$ - napthyl & $\mathrm{CH}_{3}$ & -12.21 & -8.57 & -8.67 & -9.59 \\
\hline SRS 77 & $\alpha$ - napthyl & $\mathrm{NO}_{2}$ & -12.04 & -8.94 & -8.88 & -9.54 \\
\hline SRS 78 & $\alpha$ - napthyl & $\mathrm{C}_{6} \mathrm{H}_{5}$ & -9.23 & -3.25 & -10.91 & -10.27 \\
\hline SRS 79 & $4-\mathrm{O} \mathrm{CH}$ & $\mathrm{Br}$ & -6.83 & -6.30 & -8.88 & -11.16 \\
\hline SRS 80 & $4-\mathrm{OCH}_{3}$ & $\mathrm{Cl}$ & -8.65 & -6.57 & -8.47 & -7.94 \\
\hline SRS 81 & $4-\mathrm{O} \mathrm{CH}$ & $\mathrm{CH}_{3} \mathrm{O}$ & -8.14 & -3.90 & -8.67 & -7.94 \\
\hline SRS 82 & $4-\mathrm{C} \mathrm{CH}_{3}$ & $\mathrm{CH}_{3}$ & -5.76 & -7.01 & -7.87 & -11.74 \\
\hline SRS 83 & $4-\mathrm{O} \mathrm{CH}_{3}$ & $\mathrm{NO}_{2}$ & -8.07 & -5.32 & -10.43 & -7.44 \\
\hline SRS 84 & $4-\mathrm{C} \mathrm{CH}_{3}$ & $\mathrm{C}_{6} \mathrm{H}_{5}$ & -0.58 & -4.79 & -7.65 & -8.15 \\
\hline SRS 85 & 3,4 -di- $-\mathrm{CH}_{3}$ & $\mathrm{Br}$ & -10.12 & -6.28 & -10.52 & -11.80 \\
\hline SRS 86 & 3,4 -di- $\mathrm{CH}_{3}$ & $\mathrm{Cl}$ & -7.26 & -7.81 & -10.96 & -12.02 \\
\hline SRS 87 & $3,4-\mathrm{di}-\mathrm{CH}_{3}$ & $\mathrm{CH}_{3} \mathrm{O}$ & -10.32 & -7.08 & -10.86 & -10.17 \\
\hline SRS 88 & $3,4-\mathrm{di}-\mathrm{CH}_{3}$ & $\mathrm{CH}_{3}$ & -9.20 & -5.52 & -11.44 & -12.02 \\
\hline SRS 89 & 3,4-di- $\mathrm{CH}_{3}$ & $\mathrm{NO}_{2}$ & -7.96 & -5.70 & -10.99 & -7.14 \\
\hline SRS 90 & 3,4 -di- $\mathrm{CH}_{3}$ & $\mathrm{C}_{6} \mathrm{H}_{5}$ & -11.00 & -4.62 & -9.55 & -7.99 \\
\hline SRS 91 & 2,4,5-tri-Cl & $\mathrm{Br}$ & 10.56 & -7.53 & -10.03 & -9.23 \\
\hline SRS 92 & 2,4,5-tri-Cl & $\mathrm{Cl}$ & -10.34 & -6.12 & -10.74 & -9.13 \\
\hline SRS 93 & 2,4,5-tri-Cl & $\mathrm{CH}_{3} \mathrm{O}$ & -11.62 & -7.82 & -10.36 & -8.36 \\
\hline SRS 94 & 2,4,5-tri-Cl & $\mathrm{CH}_{3}$ & -8.48 & -6.69 & -9.48 & -8.40 \\
\hline SRS 95 & 2,4,5-tri-Cl & $\mathrm{NO}_{2}$ & -10.64 & -4.68 & -9.90 & -7.05 \\
\hline SRS 96 & 2,4,5-tri-Cl & $\mathrm{C}_{6} \mathrm{H}_{5}$ & -7.83 & -4.86 & -9.21 & -8.60 \\
\hline SRS 97 & 2,4-di- $\mathrm{CH}_{3}$ & $\mathrm{Br}$ & -7.52 & -6.34 & -9.84 & -7.98 \\
\hline SRS 98 & 2,4-di- $\mathrm{CH}_{3}$ & $\mathrm{Cl}$ & -10.09 & -5.96 & -10.06 & -8.44 \\
\hline SRS 99 & $2,4-\mathrm{di}-\mathrm{CH}_{3}$ & $\mathrm{CH}_{3} \mathrm{O}$ & -10.25 & -5.92 & -9.60 & -6.51 \\
\hline SRS 100 & 2,4-di- $\mathrm{CH}_{3}$ & $\mathrm{CH}_{3}$ & -9.97 & -6.14 & -9.84 & -8.60 \\
\hline SRS 101 & $2,4-\mathrm{di}-\mathrm{CH}_{3}$ & $\mathrm{NO}_{2}$ & -8.11 & -6.49 & -9.62 & -7.38 \\
\hline SRS 102 & $2,4-\mathrm{di}-\mathrm{CH}_{3}$ & $\mathrm{C}_{6} \mathrm{H}_{5}$ & -7.26 & -6.22 & -7.53 & -6.12 \\
\hline
\end{tabular}




\section{RESULTS AND DISCUSSION:}

Docking studies: A large number of HIV protein crystal structures have been reported in the literature which has different conformations. In this work we have considered four crystal structures (PDB ID: 1RT2, 1JLB, 3BGR and 1FK9) that are co-crystallized with inhibitors TNK 651, Nevirapine, BHAP and Rilpivirine respectively. Docking studies were performed using Glide v5.0 on four high resolution crystal structures of HIV protein with their binding modes of quality and molecular interactions between differently substituted imidazole analogs and results of which are depicted in Table 1.

The reliability of the docking results was first checked by comparing the best docking poses obtained for the co-crystallized inhibitor with its bound conformation. This was done by removing each ligand from their active site and subjecting again to redocking into the binding pocket in the conformation found in the crystal structure. As a result, a root mean square deviation (RMSD) of $1.728 \mathrm{~A}^{\circ}, 1.142 \mathrm{~A}^{\circ}, 1.248 \mathrm{~A}^{\circ}$ and $2.001 \mathrm{~A}^{\circ}$ for HIV proteins PDB ID: 1RT2, 1JLB, 3BGR and 1FK9 co-crystalized TNK 651, Nevirapine, BHAP and Rilpivirine respectively were found suggesting that the docking procedure could be relied onto predict the binding mode of our compounds.

The X-ray structure of the HIV-protein cocrystallized with TNK-651 was taken from the protein data bank; PDB ID 1RT2. The HIV protein binding site contains the important residues Lys 101A, Tyr 101A, Leu 100A, Val 106A, Tyr 188A, Tyr 181A Val 179A and Glu 138 B. The imidazole scaffold is favourably embedded in the hydrophobic pocket surrounded by the side chains of Leu 101 A, Tyr 101 A and Val 106 A. The compound also shows one H-bond interaction between the hydrophilic spacer group $\mathrm{SH}_{\text {IMIDAZOLE }}$ RING $-\mathrm{CO}_{\mathrm{LYS} 101}=1.909 \mathrm{~A}^{\circ}$ and $\mathrm{N}$ of imidazole ring_ $\mathrm{NH}_{\mathrm{LYS} 101}=2.262 \mathrm{~A}^{\circ}$.

These interactions may be responsible for the binding affinity of the molecule as indicated by the docking scores - 12.47 comparable and more than the docking score -12.04 of the reference ligand Tnk 651.

CONCLUSION: A number of newly designed imidazole analogs 1 - 102 were docked into the active sites of four crystal structures of HIV protein (PDB ID 1RT2, 1JLB, 3BGR and 1FK9) in order to investigate the possible interactions between the designed imidazole analogs and the active site of the non nucleoside reverse transcriptase protein HIV inhibitor protein. The binding mode analysis of the compounds with the highest docking scores was carried out and was compared with that of the co-crystallized ligands and co-crystalized TNK 651, Nevirapine, BHAP and Rilpivirine respectively.

It was found that compound 73 showed the highest docking score -12.47 in the active site of the HIV protein of 1RT2. Compound 73 exhibited one hydrogen bond interaction and the dock score (12.47) was also higher than that of the reference standard TNK 651 (- 12.04) while compound 76, compound 77, compound 34, compound 45 and compound 90 showed highest docking score of 12.21 , - 12.07, - 12.14, - 12.11 and - 11.90 respectively in the active sites of various HIV proteins.

ACKNOWLEDGMENT: The authors acknowledge University Grants Commission for providing financial support in the form of a Major Research Project. One of the authors (RS) thankfully acknowledges the University Grants Commission Major Research Project (UGC-MRP) for the award of fellowship during the work.

CONFLICT OF INTEREST: Authors declare no conflict of interest.

\section{REFERENCES:}

1. Jonckheere H, Anne J and De clerq E: The HIv-1 reverse transcriptase (RT) process as target for RT inhibitors, med res, Rev. 2000; 20: 129-154.

2. Singh R, Gupta S, Singh J and Arsi T: Azoles as nonnucleoside reverse transcriptase inhibitors (NNRTIs): mini review. Int J Pharm Sci Res. 2017; 8(1): 29-34.

3. De Clercq E: J. Med. Chem. 2005; 48: 1297-1313.

4. De Clercq E: Nat. Rev. Drug Discovery. 2007; 6: 10011018.

5. Hajos G, Riedi S, Molnar J and Szabo D: Non-nucleoside reverse transcriptase inhibitors, Drugs Future. 2000; 25: 47-62.

6. Ren J, Milton J, Weaver KL, Short SA, Stuart DI and Stammers DK: Structural basis for the resilience of Efavirenz (DMP-266) to drug resistance mutations in HIV1 reverse transcriptase, Strucure. 2000; 8: 1089-1094.

7. Pedersen OS and Pedersen OB: Non-nucleoside reverses transcriptase inhibitors: the NNRTI boom, Antiv. Chem. Chemother. 1999; 10: 285-314. 
8. Artico M: Selected non-nucleoside reverse transcriptase inhibitors (NNRTIs): the DABOs family. Drug Fut. 2002; 27: 159.

9. Marongiu ME, Pani A, Musiu C, La Colla P, Mai A, Sbardella G, Massa S and Artico M: 3,4-Dihydro-2alkoxy-6-benzyl-oxopyrimidines (DABOs): development of a potent class of non-nucleoside reverse transcriptase inhibitors. Recent Res. Develop. Med. Chem. 2002; 1: 65.

10. Marongiu ME, Pani A, Artico M, Massa S, Mai A and La Colla P: Selective inhibition of HIV-1 replication by a novel series of 2-substituted 6-benzyl-pyrimidines. VIII International Conference on AIDS. 1992; 19-24.

11. Pauwels R, Andries K, Desmyter J, Schols D, Kukla MJ, Breslin HJ, Raeymaeckers A, Van Gelder J, Woestenborghs R and Heykants J: Potent and selective inhibition of HIV-1 replication in vitro by a novel series of TIBO derivatives. Nature. 1990; 343: 470-474.

12. Barreca ML, Rao A, De Luca L, Iraci N, Monforte AM, Maga G, Clercq ED, Pannecouque C, Balzarini J and
Chimirri A: Discovery of novel benzimidazolones as potent non-nucleoside reverse transcriptase inhibitors active against wild-type and mutant HIV-1 strains. Bioorg Med Chem Lett. 2007; 17: 1956-1960.

13. Bernstein FC, Koetzle TF, Williams GJB, Meyer EF, Brice MD, Rodgers JR, Kennard O, Shimanovichi T and Tasumi M: The protein data bank: a computer-based archival le for macromolecular structures. J. Mol. Biol. 1977; 112: 535542.

14. Kuntz ID: Science. 1992; 257: 1078-1082.

15. Lybrand TP: Curr. Opin. Struct. Biol. 1995; 5: 224-228.

16. Abagyan R and Totrov M: Curr. Opin. Chem. Biol. 2001; 5: $375-382$.

17. Das K, Lewib PJ, Hughesc SH and Arnold E: Crystallography and the design of anti-AIDS drugs: conformational flexibility and positional adaptability are important in the design of nonnucleoside HIV-1 reverse transcriptase inhibitors. Prog Biophys Mol Biol. 2005; 88: 209-231.

How to cite this article:

Singh R and Ganguly S: Molecular docking studies of novel imidazole analogs as HIV-1-RT inhibitors. Int J Pharm Sci Res 2017; 8(9): 3751-57.doi: 10.13040/IJPSR.0975-8232.8(9).3751-57.

All ๑ 2013 are reserved by International Journal of Pharmaceutical Sciences and Research. This Journal licensed under a Creative Commons Attribution-NonCommercial-ShareAlike 3.0 Unported License.

This article can be downloaded to ANDROID OS based mobile. Scan QR Code using Code/Bar Scanner from your mobile. (Scanners are available on Google Playstore) 